\title{
Notes
}

\section{From Private Places to Private Activities: Toward a New Fourth Amendment House for the Shelterless}

\author{
Michael D. Granston
}

The law, in its majestic equality, forbids the rich as well as the poor to sleep under bridges....

- Anatole France*

\section{INTRODUCTION}

During the past decade, homelessness in the United States has increased dramatically. Current estimates of the homeless population range from 250,000 to $3,000,000$ people nationwide. ${ }^{1}$ These estimates also indicate that the homeless population is continuing to grow, with cities throughout the United States reporting annual increases in homelessness of fifteen to fifty percent. ${ }^{2}$

* John Cournos, A Modern PluTARCh 27 (1928).

1. Advocacy groups such as the National Coalition on the Homeless and the Committee for Creative Non-Violence estimate the homeless population to be as high as 3,000,000 people nationwide. Robert C. Coates, Legal Rights of Homeless Americans, 24 U.S.F. L. REV. 297, 298 (1990); Kathleen Peroff, Who Are the Homeless and How Many Are There?, in THE HOMELESS IN CONTEMPORARY SOCIETY 42 (Richard D. Bingham et al. eds., 1987) [hereinafter CONTEMPORARY SOCIETY]. By contrast, the recent census report estimates the homeless population to be approximately 230,000 nationwide. Dennis Hevesi, Census Count of Homeless is Disputed, N.Y. TMIES, Apr. 13, 1991, at A26.

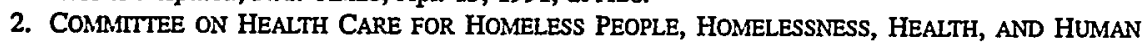
NEEDS 3 (1988) [hereinafter HEALTH CARE]; see also THE PARTNERSHIP FOR THE HOMELESS, INC., MOVING FORWARD: A NATIONAL AGENDA TO ADDRESS HOMELESSNESS IN 1990 AND BEYOND AND A STATUS 
The surge in homelessness has outpaced the ability of private and public organizations to provide temporary shelter. In some cities, as many as eighty to ninety percent of those in need of temporary shelter are unable to obtain it. ${ }^{3}$ This scarcity of temporary shelter has created a new subclass of homeless individuals-those "shelterless" who find themselves not only without a permanent home, but also without any residential shelter whatsoever. ${ }^{4}$

As many scholars have recognized, the emergence of a shelterless class of homeless persons raises fundamental questions about issues such as the right to shelter ${ }^{5}$ and the validity of residency requirements as prerequisites to the enjoyment of certain rights and entitlements. ${ }^{6}$ However, scholars have virtually ignored the issue of shelterlessness in the context of the Fourth Amendment. ${ }^{7}$ Yet, the explicit protection that this amendment extends to "houses"8 raises

REPORT ON HOMELESSNESS IN AMERICA 6 (1989) [hereinafter PARTNERSHIP] (43 out of 46 cities surveyed experienced increases in homelessness, some as high as 70\%). But see Robert C. Ellickson, The Homelessness Muddle, PUB. INTEREST, Spring 1990, at 45, 46 (suggesting that significant percentage of reported increases may be illusory).

3. PARTNERSHP, supra note 2, at 14; see also Mary E. Stefl, The New Homeless: A National Perspective, in CONTEMPORARY SOCIETY, supra note 1, at 51 (study of homelessness in Philadelphia revealed that $43 \%$ of homeless population was shelterless); Jason DeParle, Bush Homeless Plan: 'Godsend' or False Hope?, N.Y. TTMES, Feb. 12, 1990, at A1 (each night half of New York City's homeless population, virtually 30,000 people, are shelterless). But see Ellickson, supra note 2, at 50 (arguing that number of people living on street is seasonal).

4. See Ellickson, supra note 2, at 45-46. These homeless individuals are forced to live on park benches, in abandoned buildings, on the streets, under bridges, and in other obscure places. Donna Mascari, Comment, Homeless Families: Do They Have a Right to Integrity?, 35 UCLA L. REV. 159, 162 n.12. In the homelessness literature, these people are often referred to as "streer" people. See, e.g., Peroff, supra note 1, at 34; Stefl, supra note 3 , at 50-51. However, this label does not adequately convey the myriad of nonresidential areas that the homeless are often forced to occupy. Thus, in lieu of the term "street" people, this Note will refer to those homeless unable to obtain temporary residential shelter as "shelterless" people.

5. See, e.g., Akhil R. Amar, Forty Acres and a Mule: A Republican Theory of Minimal Entitlements, 13 HARV. J.L. \& PUB. POL'Y 37 (1990) (finding right to minimum level of sustenance in Thirteenth Amendment); Frank I. Michelman, Welfare Rights in a Constitutional Democracy, 1979 WASH. U. L.Q. 659 (arguing that Fourteenth Amendment entitles each individual to minimum endowment of wealth, including right to shelter); Curtis R. Berger, Beyond Homelessness: An Entitlement to Housing, 45 U. MLAMI L. REV. 315, 324-25 (1990-91) (urging adoption of statutory right to shelter); Robert C. Ellickson, The Untenable Case for an Unconditional Right to Shelter, 15 HARV. J.L. \& PUB. POL'Y (forthcoming Winter 1992) (arguing that unconditional legal right to shelter would be counterproductive).

6. See, e.g., Coates, supra note 1, at 315-20 (discussing legal issues raised by imposition of residency requirements as prerequisite to voting and receipt of welfare benefits by homeless); Donald $P$. Tuttle et al., The Plight of the Homeless, 18 URB. LAw. 925, 927-30, 932-33 (same).

7. To date, only Douglas Lasdon has broached the question of Fourth Amendment protection for the homeless. See Douglas H. Lasdon, Beyond the Quagmire: The Fourth Amendment Rights of Residents of Private Shelters for the Homeless, 3 N.Y.U. HUM. RTS. ArN. 389 (1986). In his article, Lasdon examines the Fourth Amendment rights of residents of Covenant House, a Manhattan shelter for homeless and runaway youths. Lasdon concludes that the courts would be likely to find that the residents of Covenant House are entitled to some Fourth Amendment protection. See infra note 98. Lasdon does not discuss the Fourth Amendment rights of those unable to secure any type of temporary shelter.

8. The Fourth Amendment provides:

The right of the people to be secure in their persons, houses, papers, and effects, against unreasonable searches and seizures, shall not be violated, and no Warrants shall issue, but upon probable cause, supported by Oath or affirmation, and particularly describing the place to be searched, and the persons or things to be seized.

U.S. CONST. amend. IV. 
the important question of how this term should apply to members of society who lack any type of residence remotely resembling a traditional dwelling.

Currently, the definition of Fourth Amendment houses is controlled by the Supreme Court's decision in Katz v. United States. ${ }^{9}$ In Katz, the Court eschewed reliance on state law concepts of property and trespass for determining the scope of Fourth Amendment protection. The Court argued that new methods of governmental surveillance required the adoption of a different Fourth Amendment rule, one which focused on privacy not property interests.

In light of Katz, the courts have revised their understanding of Fourth Amendment houses. Following Katz' command to analyze Fourth Amendment interests by reference to reasonable expectations of privacy, the courts now limit Fourth Amendment protection to areas secluded from public scrutiny. The courts use public seclusion as a standard for evaluating the legitimacy of a privacy interest in a particular place.

This interpretation of Fourth Amendment houses has significant ramifications for the shelterless. Since the shelterless, almost by definition, lack premises secluded from the public, they are unlikely to receive any protection against searches of their areas of residence under an interpretation that limits Fourth Amendment houses to areas secluded from public scrutiny. ${ }^{10}$

This Note argues that the courts' understanding of Fourth Amendment houses should include the areas inhabited by the shelterless. Since the shelterless have no option but to live their daily lives in the public domain, public seclusion is an invalid measure of their expectations of privacy. Thus, this Note offers a new interpretation of Fourth Amendment houses that takes into account the phenomenon of shelterlessness as an inexorable feature of the current American landscape.

This Note proceeds in four parts. Part I discusses the Supreme Court's decision in Katz and how courts have used this decision to limit Fourth Amendment houses to areas secluded from the public. Part II examines the implications of this interpretation of Fourth Amendment houses for the shelterless and

9. 389 U.S. 347 (1967).

10. Already, several courts have refused to confer the title of Fourth Amendment "house" on areas inhabited by shelterless persons. See United States v. Ruckman, 806 F.2d 1471 (10th Cir. 1986) (cave in which defendant was living did not fall within scope of Fourth Amendment's protection of places); Transcript, State v. Mooney, No. CR8-82728 (Conn. Super. Ct. Feb. 7, 1989) (area underneath bridge abutment where defendant had been residing not entitled to protection as Fourth Amendment house), rev'd on other grounds, 588 A.2d 145 (Conn.) (warrantless search of defendant's effects violated Fourth Amendment), cert. denied, 112 S. Ct. 330 (1991); Commonwealth v. Cameroon, No. 02778 (Pa. Super. Ct. July 6,1989 ) (warrantless search of abandoned building occupied by defendant did not violate Fourth Amendment).

Of course, "houses" are not the only entities protected by the Fourth Amendment. The Fourth Amendment also extends protection to "effects." See U.S. CoNST. amend. IV. Unless the areas inhabited by the shelterless are deemed to qualify as Fourth Amendment houses, however, it is unlikely that the Fourth Amendment's protection of effects will entitle the shelterless to any independent protection against searches of these areas. See infra note 121. For this reason, if the courts do not extend protection to the places inhabited by the shelterless, the shelterless will be left with virtually no Fourth Amendment protection for their areas of residence. 
concludes that this interpretation threatens to deny completely Fourth Amendment protection for their areas of residence. Part III criticizes application of the current definition of Fourth Amendment houses to the shelterless, arguing that such an application misconceives the nature of the right embodied within the Fourth Amendment's protection of houses. Part IV concludes by advocating a new definition of Fourth Amendment houses-one that focuses on the type of activities occurring in a place, not the degree to which that place is secluded from the public.

\section{What IS A FOURTH AMENDMENT HOUSE?}

As the constitutional text indicates, the Fourth Amendment does not prohibit every unreasonable search or seizure. Only those unreasonable searches and seizures involving "persons, houses, papers, and effects" are constitutionally proscribed. " Since "papers" and "effects" refer to possessions and "persons" refers to individuals, the only term in the Fourth Amendment referring to places is "houses." ${ }^{12}$ Current Fourth Amendment jurisprudence limits the term "houses" to those areas secluded from public scrutiny.

\section{A. Katz v. United States}

Prior to the Supreme Court's ruling in Katz,$^{13}$ the Supreme Court used a "protected areas" approach to determine when a Fourth Amendment search had occurred. ${ }^{14}$ Under this standard, articulated most forcefully in Olmstead v. United States, ${ }^{15}$ only actual physical intrusions by government officials into certain protected areas violated the Fourth Amendment. The contours of these protected areas were defined by existing property rights. Consequently, a Fourth Amendment house consisted of those areas in which an individual had a property interest, and physical trespass became the litmus test for illegal searches of premises. ${ }^{16}$

11. U.S. CONST. amend. IV.

12. The dictionary defines a house as "a building for human beings to live in." WEBSTER'S NEW WORLD DICTIONARY 680 (2d ed. 1972). In the context of the Fourth Amendment, however, the word "house" has never been so restricted. See infra Part IC.

13. 389 U.S. 347 (1967).

14. Id. at $350-53$.

15. 277 U.S. 438 (1928) (wiretapping does not constitute search within meaning of Fourth Amendment).

16. See, e.g., Goldman v. United States, 316 U.S. 129, 134 (1942) (use by federal agents of detectaphone to overhear conversations through adjoining wall was not Fourth Amendment search because there was no "trespass or unlawful entry"). Not every trespass constituted a Fourth Amendment search. In Hester v. United States, for example, the Court held that the Fourth Amendment did not bar the testimony of two officers who had observed the defendant's criminal activities while trespassing on the defendant's fields. 265 U.S. 57 (1924). Hester indicates that the presence of a property interest was a necessary but not sufficient condition for Fourth Amendment protection. 
In Katz, however, the Supreme Court rejected the "protected areas" concept. ${ }^{17}$ Writing for the majority, Justice Stewart declared that "the Fourth Amendment protects people, not places." ${ }^{" 18}$ Consequently, the Court proceeded to overrule Olmstead and its progeny, stating that "the trespass doctrine there enunciated can no longer be regarded as controlling."19

It was left to the concurring opinion of Justice Harlan, however, to formulate a new standard for determining when a Fourth Amendment search occurred. He proposed the following two-part test: "First, that a person have exhibited an actual (subjective) expectation of privacy and, second, that the expectation be one that society is prepared to recognize as 'reasonable." "20 This test became the Court's prevailing standard for determining the scope of Fourth Amendment interests. ${ }^{21}$

The Supreme Court's adoption of Harlan's test was necessitated by the increasing growth and complexity of modern surveillance techniques. ${ }^{22}$ These techniques enabled governmental surveillance to occur without any "technical trespass ... under local property law." ${ }^{23}$ Thus, a Fourth Amendment wedded to property interests as the talisman of protection against unreasonable searches and seizures proved incapable of safeguarding individuals against these new forms of governmental surveillance. ${ }^{24}$ Only by shifting from property to privacy interests as the determinant of Fourth Amendment protections could the Fourth Amendment remain a viable bulwark against governmental invasion into the lives of individual citizens. ${ }^{25}$

The Supreme Court's shift from property to privacy interests was not without its costs, however. In the process of updating Fourth Amendment jurisprudence, the Court was forced to abandon the adjudicative simplicity of

17. Even before Katz, the Court began moving away from the concept of "protected areas." In Silverman v. United States, the Court declared that physical intrusion and not "niceties of tort or real property law" should determine Fourth Amendment rights. 365 U.S. 505, 511 (1961). Similarly, in Warden v. Hayden, the Court stated that "[t]he premise that property interests control the right of the Government to search and seize has been discredited." 387 U.S. 294, 304 (1967). Thus, by the time Katz was decided, the Supreme Court's repudiation of the "protected areas" concept was virtually preordained.

18. Katz, 389 U.S. at 351.

19. Id.

20. Id. at 361 (Harlan, J., concurring).

21. See, e.g., Smith v. Maryland, 442 U.S. 735, 740 (1979); Terry v. Ohio, 392 U.S. 1, 9 (1968).

22. Katz, 389 U.S. at 362 (Harlan, J., concurring) ("[The trespass doctrine's] limitation on Fourth Amendment protection is, in the present day, bad physics as well as bad law, for reasonable expectations of privacy may be defeated by electronic as well as physical invasion."); Steven C. Douse, Note, The Concept of Privacy and the Fourth Amendment, 6 U. MICH. J.L. REF. 154, 161 (1972) ("A rapidly advancing technology ... provid[ed] new means of communication and new possibilities for their interception, and new opportunities for increasingly subtle invasions of personal privacy.").

23. Katz, 389 U.S. at 353 (quoting Silverman v. United States, 365 U.S. 505, 511 (1961)).

24. See, e.g., Goldman v. United States, 316 U.S. 129 (1942); Olmstead v. United States, 277 U.S. 438 (1928) (wiretapping achieved without physical trespass into defendant's homes or offices did not constitute Fourth Amendment search).

25. See Douse, supra note 22, at 162 ("IC]hanges occurring in the quality of life in America expanded the scope of necessary privacy beyond that which derived from the benefits of a proprietary interest. It was becoming increasingly clear that the types of search and seizure envisioned by the founders did not exhaust the possible means by which the relevant 'privacies of life' might be violated."). 
the trespass doctrine. Following Katz, the courts had to determine not whether an individual had "a property interest in the invaded place," but whether the individual had "a legitimate expectation of privacy in the invaded place." 26 This latter task proved more elusive than its predecessor. ${ }^{27}$ Thus, the Court's decision in Katz resulted in the substitution "for a 'workable tool' that often proved 'unjust' a new test which was 'difficult to apply.' "'28

\section{B. The Public Exposure Doctrine}

In an effort to reduce the uncertainty engendered by the Katz test, the courts have reverted to the "protected areas" concept. ${ }^{29}$ Following Katz, however, the dispositive factor has become whether the area searched is exposed to the public, not whether it is private property. ${ }^{30}$ The rejuvenation and modification of the protected areas approach derives from Justice Harlan's concurrence in Katz, which insisted that the Fourth Amendment's protection of people "requires reference to a 'place." "31 In Harlan's view, "objects, activities, or statements that [a man] exposes to the 'plain view' of outsiders" do not warrant Fourth Amendment protection "because no intention to keep them to himself has been exhibited."

26. Rakas v. Illinois, 439 U.S. 120, 143 (1978).

27. This result is not surprising, since privacy is a much more difficult concept to define than property. See, e.g., ARTHUR MIILER, THE ASSAULT ON PRIVACY 25 (1971) (concept of privacy "is exasperatingly vague and evanescent, often meaning strikingly different things to different people"); Hyman Gross, The Concept of Privacy, 42 N.Y.U. L. REV. 34, 37-38 (1967) (privacy may, in different contexts, refer to different types of relationships between individual actor and his environment).

28. I WAYNE R. LAFAVE \& JEROLD H. ISRAEL, CRMMNAL PROCEDURE 163 (1984). According to one commentator, the Katz test's failure to provide any concrete guidance made adjudication under this standard tantamount to "wav[ingl Justice Harlan's magic wand." Brian J. Serr, Great Expectations of Privacy: A New Model for Fourth Amendment Protection, 73 MINN. L. REV. 583, 593 (1989).

The switch from privacy to property interests exacted a cost in addition to the administrative difficulties it engendered. As long as Fourth Amendment interests were defined by reference to property law, the states exercised significant control over the Fourth Amendment's contours. By redefining the property interests of its citizens, the states could, in effect, redefine its citizens' Fourth Amendment rights. When Katz divorced Fourth Amendment interests from property law, it reduced the ability of the states to counteract federal government encroachment upon Fourth Amendment interests. (1977).

29. See Note, A Reconsideration of the Katz Expectation of Privacy Test, 76 MICH. L. REV. 154, 169

30. See Serr, supra note 28, at 597-98; James J. Tomkovicz, Beyond Secrecy for Secrecy's Sake: Toward an Expanded Vision of the Fourth Amendment Privacy Province, 36 HASTINGs L.J. 645, 655 (1985); see also cases cited infra Part LC. Public exposure has also become the courts' talisman for determining the Fourth Amendment's protection of papers and effects. See, e.g., California v. Greenwood, 486 U.S. 35 (1988) (defendant had no reasonable expectation of privacy in garbage left in place accessible to public); United States v. Miller, 425 U.S. 435 (1976) (defendant had no reasonable expectation of privacy in bank records exposed to bank employees).

31. Katz, 389 U.S. at 361 (Harlan, J., concurring).

32. Id. Justice Stewart echoed a similar sentiment in his majority opinion. He stated that "what a person knowingly exposes to the public, even in his own home or office, is not a subject of Fourth Amendment protection." Id. at 351. Neither Justice Harlan nor Justice Stewart explained what they meant by public exposure. In subsequent decisions, the courts have come to view public exposure as a relative concept, one which varies with the nature of the area in question. See infra Part I.C. 
The Supreme Court justified the emphasis on public exposure in Oliver $v$. United States. ${ }^{33}$ Since areas exposed to the public do not normally "provide the setting for those intimate activities that the Amendment is intended to shelter from government surveillance," the Court reasoned, expectations of privacy in such areas are not expectations "that society recognizes as reasonable." ${ }^{\text {34 }}$ Thus, the Court concluded, publicly exposed areas are not entitled to protection as Fourth Amendment houses under the Katz test. ${ }^{35}$

This emphasis on public exposure demonstrates that Katz' shift from property to privacy interests has not reduced the courts' adherence to formulaic Fourth Amendment solutions.$^{36}$ Rather, the primary effect of Katz has largely been to replace one formula with another. In the context of the Fourth Amendment's protection of places, this has meant a shift from trespass to public exposure as the talisman of Fourth Amendment houses. ${ }^{37}$

\section{Prototypical Fourth Amendment Houses}

Under the auspices of the public exposure doctrine, the courts have limited Fourth Amendment protection to roughly five types of areas: residential dwellings, commercial premises, curtilage, quasi-private public areas, and motor vehicles. While acknowledging that individuals may possess subjective expectations of privacy in other settings, the courts have held that only in these specific areas, due to their secluded nature, are such expectations reasonable.

\section{Residential Dwellings}

Houses are the prototypical places specified in the Constitution as deserving of Fourth Amendment protection. It is not surprising, therefore, that the courts have treated subjective expectations of privacy in houses as presumptively

33. 466 U.S. 170 (1984) (seizure of marijuana growing in woods on defendant's land did not constitute Fourth Amendment search).

34. Id. at 179.

35. As Oliver indicates, the courts have come to use the concept of public exposure as a measure of the second prong of the Katz test, whether an expectation of privacy is one which society would accept as reasonable. In contrast, Justice Harlan viewed public exposure as a measure of the first prong of the Katz test, whether an expectation of privacy actually existed. See supra text accompanying note 32 .

36. Professor Amsterdam believes that one of Katz' main objectives was to reject formulaic approaches to Fourth Amendment adjudication. According to Amsterdam, "the Katz decision was written to resist captivation in any formula. An opinion which sets aside prior formulas with the observation that they cannot 'serve as a talismanic solution to every Fourth Amendment problem' should hardly be read as intended to replace them with a new talisman." Anthony G. Amsterdam, Perspectives on the Fourth Amendment, 58 ManN. L. REV. 349, 385 (1974) (quoting Katz, 389 U.S. at 351 n.9).

37. Public exposure has become a talisman of Fourth Amendment interests only to the extent that seclusion from the public is a necessary condition for Fourth Amendment protection. In many instances, the courts have relied upon the first prong of the Katz test to deny Fourth Amendment protection even when the area searched was secluded from the public. See, e.g., United States v. Matlock, 415 U.S. 164 (1974) (third party's consent to search of bedroom negated defendant's claim to actual expectation of privacy). Thus, seclusion from the public is not, by itself, a sufficient condition for Fourth Amendment protection. Cf. supra note 16 . 
reasonable and warrantless searches of houses as presumptively unreasonable. ${ }^{38}$ Since $K a t z$, the courts have justified this special treatment on the grounds that houses constitute enclosed structures particularly well suited to sheltering private activities. ${ }^{39}$

The special protection conferred upon houses has been extended to other residential dwellings. These dwellings have included apartment buildings, ${ }^{40}$ boarding houses, ${ }^{41}$ motel rooms, ${ }^{42}$ and dormitories. ${ }^{43}$ Not all residential dwellings have received Fourth Amendment protection, however. When dwellings or parts thereof have been found to be lacking those seclusive features characteristic of traditional houses, the courts have refused to recognize these areas as protected places. Thus, the courts have denied Fourth Amendment protection to motel rooms after checkout, ${ }^{44}$ to common areas of multifamily dwellings, ${ }^{45}$ and to dwellings inhabited by trespassers. ${ }^{46}$ In each case, the courts concluded that the subject of the search did not have a right to exclude third parties from the searched premises, and therefore, that the premises lacked those elements of seclusion traditionally characterizing residential dwellings. ${ }^{47}$

\section{Commercial Premises}

In See v. City of Seattle, ${ }^{48}$ the Supreme Court held that the Fourth Amendment's protection of places extended to a commercial warehouse. According to the Court, the warehouse was "not open to the public," and thus the owner, "like the occupant of a residence, ha[d] a constitutional right to go about his business free from unreasonable official entries." ${ }^{49}$ This right was violated,

38. See, e.g., Payton v. New York, 445 U.S. 573, 586 (1980) ("It is "a basic principle of Fourth Amendment law' that searches and seizures inside a home without a warrant are presumptively unreasonable.") (quoting Coolidge v. New Hampshire, 403 U.S. 443, 477 (1971)).

39. See Oliver, 466 U.S. at 179.

40. See, e.g., United States v. Carriger, 541 F.2d 545 (6th Cir. 1976).

41. See, e.g., State v. Person, 298 N.E.2d 922 (Ohio 1973).

42. See, e.g., Pate v. Municipal Court, 89 Cal. Rptr. 893 (Ct. App. 1970).

43. See, e.g., Smyth v. Lubbers, 398 F. Supp. 777 (W.D. Mich. 1975).

44. See, e.g., United States v. Parizo, 514 F.2d 52 (2d Cir. 1975).

45. See, e.g., State v. Crider, 341 A.2d 1 (Me. 1975). But see State v. Reddick, 541 A.2d 1209 (Conn. 1988) (defendant had legitimate expectation of privacy in basement despite its use as common area by other inhabitants of multifamily dwelling).

46. See, e.g., Amezquita v. Hernandez-Colon, 518 F.2d 8 (1st Cir. 1975) (squatters had no legitimate expectation of privacy in houses built on land owned by Puerto Rico), cert. denied, 424 U.S. 916 (1976); People v. Sumlin, 431 N.Y.S.2d 967 (Crim. Ct. 1980) (trespasser in city-owned abandoned building did not possess reasonable expectation of privacy). These cases demonstrate that the trespass doctrine has returned in limited form-except in reverse. The determinative issue now is not whether the police were trespassing, see Oliver v. United States, 466 U.S. 170 (1984) (upholding warrantless search of private field), but whether the defendant himself was trespassing.

47. Cf. Minnesota v. Olson, 110 S. Ct. 1684, 1689-90 (1990) (house guest possesses sufficient dominion and control over host's premises to challenge warrantless search of premises); State v. Dias, 609 P.2d 637 (Haw. 1980) (squatters' huts entitled to Fourth Amendment protection because society had come to accept squatters as legal possessors of area searched).

48. 387 U.S. 541 (1967).

49. Id. at 543,545 . 
the Court concluded, by an official inspection of the warehouse "without a suitable warrant procedure." 50

Both federal and state courts have used the See decision to extend Fourth Amendment protection to a variety of commercial and business premises. ${ }^{51}$ However, as with residential dwellings, the courts have refused to extend Fourth Amendment protection to commercial premises deemed to be exposed to the public. ${ }^{52}$ Thus, the courts have routinely denied Fourth Amendment protection to those premises or parts of premises accessible to the general public. ${ }^{53}$

\section{Open Fields}

In contrast to residential and commercial premises, open fields have generally been denied protection as Fourth Amendment houses. ${ }^{54}$ After Katz, this denial of protection has been justified on the ground that open fields are not capable of serving as private enclaves. As the Court explained in Oliver, open fields "are usually accessible to the public and police in ways that a home, an office, or commercial structure would not be."55

Although Oliver concerned police conduct in the open fields, the Court made it clear that the "open fields" doctrine was not limited merely to open fields. "An open field," the Court explained, "need be neither 'open' nor a 'field' as those terms are used in common speech. For example ... a thickly wooded area nonetheless may be an open field as that term is used in construing the Fourth Amendment." ${ }^{\text {"6 }}$ Following Oliver's lead, other courts have generally considered open fields to encompass any nonenclosed area. ${ }^{57}$ Thus,

50. Id. at 546.

51. See, e.g., Marshall v. Barlow's, Inc., 436 U.S. 307 (1978) (factory); Mancusi v. DeForte, 392 U.S. 364 (1976) (business office); People v. Williams, 124 Cal. Rptr. 253 (Ct. App. 1975) (airline baggage room); People v. Ramsey, 77 Cal. Rptr. 249 (Ct. App. 1969) (industrial complex); State v. Baker, 271 A.2d 435 (N.J. Super. Ct. App. Div. 1970) (back room of store).

52. 1 LAFAVE \& ISRAEL, supra note 28 , at 173.

53. See, e.g, Commonwealth v. Monteririo, 348 N.E.2d 449 (Mass. App. Ct. 1976) (upholding warrantless search of bar); Wilson v. Commonwealth, 475 S.W.2d 895 (Ky. Ct. App. 1971) (upholding warrantless search of display area in furniture store). The Supreme Court has also denied Fourth Amendment protection to the premises of "highly regulated" businesses. See, e.g., New York v. Burger, 482 U.S. 691 (1987) (upholding warrantless search of auto junkyard); Donovan v. Dewey, 452 U.S. 594 (1981) (upholding statute authorizing warrantless inspections of mines). Although the Court has not explicitly sanctioned such a view, this alternative basis for denying Fourth Amendment protection to business premises may be seen merely as an additional means by which commercial premises are "exposed" to the public. Cf. infra note 75 and accompanying text.

54. This denial of Fourth Amendment protection dates back to Justice Holmes' declaration in Hester $v$. United States that "the special protection accorded by the Fourth Amendment to the people in their 'persons, houses, papers, and effects,' is not extended to the open fields. The distinction between the latter and the house is as old as the common law." 265 U.S. 57, 59 (1923).

55. 466 U.S. 170,179 (1984).

56. Id. at 180 n.11.

57. The open fields doctrine has even been applied to areas fenced or posted with no trespassing signs. See, e.g., McDowell v. United States, 383 F.2d 599 (8th Cir. 1967). But see State v. Wert, 550 S.W.2d 1 (Tenn. Ct. App. 1977) (presence of sign and fence gave rise to reasonable expectation of privacy in open fields). This conception of the open fields doctrine was defended by the Supreme Court in Oliver, in which 
the courts have applied the "open fields" doctrine to areas such as vacant lots, ${ }^{58}$ beaches, ${ }^{59}$ groves, ${ }^{60}$ deserts, ${ }^{61}$ and reservoirs. ${ }^{62}$

Extension of protection to the curtilage is the one exception the courts have made to the practice of denying Fourth Amendment protection to open fields. The curtilage consists of those areas that are used and enjoyed as "adjunct[s] to the domestic economy of the family." 63 Due to this close connection between the curtilage and the home, the courts have argued that the curtilage is an area where "intimate activity associated with the 'sanctity of a man's home and the privacies of life" " is likely to occur. ${ }^{64}$ Thus, the curtilage ought to be "considered part of the home itself for Fourth Amendment purposes."65

the Court stated that "the test of legitimacy is not whether the individual chooses to conceal assertedly 'private' activity. ... . Certainly the Framers did not intend that the Fourth Amendment should shelter criminal activity wherever persons with criminal intent choose to erect barriers and post 'No Trespassing' signs." Oliver, 466 U.S. at $182 \&$ n.13.

58. See, e.g., State v. Stavricos, 506 S.W.2d 51 (Mo. Ct. App. 1974).

59. See, e.g., Anderson v. State, 209 S.E.2d 665 (Ga. Ct. App. 1974).

60. See, e.g., United States v. Pruitt, 464 F.2d 494 (9th Cir. 1972).

61. See, e.g., State v. Caldwell, 512 P.2d 863, 867 (Ariz. Ct. App. 1973).

62. See, e.g., State v. Borchard, 264 N.E.2d 646 (Ohio Ct. App. 1970).

63. Care v. United States, 231 F.2d 22, 25 (10th Cir.), cert. denied, 351 U.S. 932 (1956); see also Oliver, 466 U.S. at 180 (curtilage consists of "the land immediately surrounding and associated with the home."). In United States v. Dunn, the Supreme Court articulated four criteria for determining whether an area is to be considered part of the curtilage for Fourth Amendment purposes:

[T] he proximity of the area claimed to be curtilage to the home, whether the area is included within an enclosure surrounding the home, the nature of the uses to which the area is put, and the steps taken by the resident to protect the area from observation by people passing by. 480 U.S. 294, 301 (1987).

64. Dunn, 480 U.S. at 300 (quoting Boyd v. United States, 116 U.S. 616, 630 (1886)).

65. Oliver, 466 U.S. at 180 . On first blush, it may seem that the curtilage's protected status constitutes an exception to the public exposure doctrine. Yet, as the definition of the curtilage indicates, the curtilage has no independent status as a protected area; rather, the curtilage is entitled to Fourth Amendment protection solely by virtue of its connection to a residential dwelling-an area which is itself secluded from public scrutiny. Furthermore, although the Supreme Court has paid lip service to the protected status of the curtilage, the Court has never actually invalidated a police search on the grounds that it constituted an impermissible intrusion on the curtilage. Each time the Court has been asked to so rule, the Court has found an alternative basis for upholding the intrusion in question. See, e.g., Florida v. Reilly, 488 U.S. 445 (1989) (aerial surveillance by police in helicopter 400 feet above defendant's greenhouse justified by plain view doctrine); Dunn, 480 U.S. 294 (barn located outside fence around residence and 60 yards from houses not in curtilage); Dow Chem. Co. v. United States, 476 U.S. 227 (1986) (partially enclosed industrial complex more like open fields than curtilage); California v. Ciraolo, 476 U.S. 207 (1986) (warrantless aerial surveillance by police of defendant's fenced-in backyard from navigable airspace justified by plain view doctrine). Thus, the extent to which the curtilage remains a protected area under current Fourth Amendment jurisprudence is unclear. However, since the lower courts have not been as hesitant to extend constitutional status to the curtilage, see, e.g., United States v. Dunn, 782 F.2d 1226 (5th Cir. 1986) (police search of defendant's barn without warrant constituted impermissible intrusion onto curtilage), rev'd, 480 U.S. 294; United States v. Van Dyke, 643 F.2d 992 (4th Cir. 1981) (honeysuckle patch "situated within exclusionary fence" part of curtilage); People v. Lovelace, 172 Cal. Rptr. 65 (Ct. App. 1981) (defendant had reasonable expectation of privacy in backyard surrounded by six-foot fence), it is likely that the curtilage will remain part of the amalgam of areas qualifying as Fourth Amendment houses until the Supreme Court officially decides to the contrary. 


\section{Quasi-Private Public Areas}

The courts have generally denied Fourth Amendment protection to public places, frequently under the rubric of the "open fields" doctrine. When these public areas have consisted of enclosed spaces, however, the courts have predicated Fourth Amendment protection on whether or not these areas were intended to be places of temporary privacy, "whose momentary occupant" had a right to expect "freedom from intrusion." 66

In Katz, for example, the Court held that a telephone booth constituted a protected area. In his concurring opinion, Justice Harlan justified this holding on the grounds that although a "booth is 'accessible to the public' at other times ... '[o]ne who occupies it ... [and] ... pays the toll that permits him to place a call is surely entitled to assume' that his conversation is not being intercepted."67

Following Katz' lead, the lower courts have extended Fourth Amendment protection to other public areas like dressing rooms ${ }^{68}$ and bathroom stalls. ${ }^{69}$ This protection has been extended on the ground that these places, like telephone booths, constitute areas whose occupants are entitled to momentary privacy. However, when these areas have been constructed so as to be open to general public scrutiny, the courts have refused to treat them as Fourth Amendment houses. The courts have reasoned that "when the design is such that there is no right to expect privacy there can be no invasion of privacy."70

\section{Motor Vehicles}

Though motor vehicles are technically effects, the Supreme Court has often treated them as places for Fourth Amendment purposes. To determine the protection to be accorded to such vehicles, the Court has made comparisons to other protected areas such as residential dwellings. In the process, the Court has concluded that although cars are sufficiently "enclosed" to warrant constitutional protection, ${ }^{71}$ they "are not to be treated identically with houses or apartments for Fourth Amendment purposes." 72 Thus, the Court has held that a governmental official may, if justified by the surrounding circumstances, conduct a vehicle search without a warrant. ${ }^{73}$

66. Katz v. United States, 389 U.S. 347, 361 (1967) (Harlan, J., concurring).

67. Id. (quoting Katz, 389 U.S. at 352).

68. See, e.g., State v. McDaniel, 337 N.E.2d 173 (Ohio Ct. App. 1975).

69. See, e.g., Kroehler v. Scott, 391 F. Supp. 1114 (E.D. Pa. 1975).

70. Buchanan v. State, 471 S.W.2d 401, 404 (Tex. Ct. App. 1971) (surveillance of bathroom stall without doors did not constitute Fourth Amendment search).

71. California v. Carney, 471 U.S. 386, 390, 391 (1985).

72. Rakas v. Illinois, 439 U.S. 128, 148 (1978).

73. See, e.g., Carney, 471 U.S. 386; United States v. Ross, 456 U.S. 798 (1982). The official must still possess probable cause before searching the vehicle. Coolidge v. New Hampshire, 403 U.S. 443, 458 (1971). 
Initially, the Court justified this disparate treatment by reference to the ability of vehicles to be "quickly moved." "74 Since Katz, however, the Court has based this lesser degree of protection largely on the ground that cars are more exposed to the public than are houses or apartments because of the "pervasive regulation" to which they are subject. ${ }^{75}$ Thus, as it has done with other places, the Court has determined the constitutional status of cars by analyzing their degree of exposure to the public.

\section{No FOURTH AMENDMENT HOUSE FOR THE SHELTERLESS}

Not surprisingly, the premises the shelterless inhabit do not fit easily into any of the general categories of places to which the courts have extended Fourth Amendment protection. ${ }^{76}$ By definition, the shelterless include those individuals unable to procure premises possessing seclusionary elements comparable to traditional forms of shelter. Consequently, under a Fourth Amendment framework where public exposure constitutes the litmus test for protection against unreasonable searches of premises, the areas inhabited by the shelterless will necessarily be excluded from Fourth Amendment protection.

\section{A. Open Areas}

Many of the places inhabited by the shelterless are likely to be excluded from Fourth Amendment protection as open fields. These places include park benches, steam grates, alleyways, areas beneath bridges, and other shelterless habitats lacking any significant degree of enclosure. Of course, there is a significant difference between the open areas inhabited by the shelterless and other open areas which the courts have deemed part of the open fields. The former constitute their occupant's primary area of residence. The Supreme Court's decision in California v. Carney, ${ }^{77}$ however, suggests that this difference is unlikely to prevent the open areas inhabited by the shelterless from being classified as open fields.

In Carney, the Supreme Court upheld a warrantless search of Carney's mobile home. At the time of the search, Carney was using the mobile home

74. Carroll v. United States, 267 U.S. 132, 153 (1925).

75. Carney, 471 U.S. at 392. The Supreme Court explained in South Dakota v. Opperman: Automobiles, unlike homes, are subjected to pervasive and continuing regulation and controls, including periodic inspection and licensing requirements. As an everyday occurrence, police stop and examine vehicles when license plates or inspection stickers have expired, or if other violations, such as exhaust fumes or excessive noise, are noted, or if headlights or other safety equipment are not in proper working order.

428 U.S. 364, 368 (1976). The Court has used the pervasive regulation rationale to apply a lower standard of Fourth Amendment protection even to vehicles unlikely to be moved. See Cady v. Dumbrowski, 413 U.S. 433 (1973) (upholding warrantless search of disabled vehicle).

76. Cf. Lasdon, supra note 7, at 390 (homeless shelters such as New York's Covenant House are "unlike most private or public areas encountered in Fourth Amendment jurisprudence").

77. 471 U.S. 386 (1985). 
as his living quarters. Nonetheless, the Court validated the search of the mobile home under the Fourth Amendment's "automobile exception." acknowledged that, unlike ordinary motor vehicles, the mobile home "possessed some, if not many of the attributes of a home," but found this distinction insufficient to alter the mobile home's Fourth Amendment status. ${ }^{79}$

The recent Connecticut case of State v. Mooney ${ }^{80}$ indicates that the courts are likely to follow a similar approach with regard to the open areas occupied by the shelterless. In Mooney, the defendant had been living for about one month under a bridge abutment spanning a highway entrance ramp when he was arrested for felony murder. During the defendant's detention at the police station, two policemen approached the defendant's girlfriend and requested her to lead them to the defendant's place of residence. She took the police to the area underneath the bridge abutment where the defendant had been residing. The police searched the area and discovered some of the defendant's belongings. These belongings were brought back to the police station, where a search revealed evidence linking the defendant to the murder.

Emphasizing the open nature of the area searched, the trial court denied the defendant's motion to suppress the evidence. According to the court, the defendant and his belongings were out in the open for anyone to observe who might be walking by. ${ }^{81}$ To highlight this fact, the court pointed out that a transportation department worker once came upon the defendant as he was clearing brush underneath the abutment. ${ }^{82}$ This encounter convinced the court that the area was not entitled to Fourth Amendment protection, despite the fact that it constituted the defendant's home.

\section{B. Enclosed Areas}

Not all shelterless persons inhabit areas as open to the public as the area in Mooney. Many shelterless individuals reside in more enclosed places such as shanties ${ }^{83}$ tunnels ${ }^{84}$ or abandoned buildings. ${ }^{85}$ Certainly there is a difference in the degree to which these latter areas are exposed to the public as

78. See supra text accompanying notes 71-73.

79. Carney, 471 U.S. at 393.

80. Transcript, No. CR8-82728 (Conn. Super. Ct. Feb. 7, 1989), rev'd on other grounds, 588 A.2d 145 (Conn.) (warrantless search of defendant's effects violated Fourth Amendment), cert. denied, $112 \mathrm{~S}$. Ct. 330 (1991).

81. Id. at 2.

82. Id. at 3 .

83. See, e.g., John Kifner, Tent City in Tompkins Square Park is Dismantled, N.Y. TMMES, Dec. 15, 1989, at B1 (over 90 homeless people inhabited tentlike structures in New York City's Tompkins Square park); San Francisco's Mayor Ousts Homeless Camp, N.Y. TMES, July 6, 1990, at A10 [hereinafter Homeless Campl (over 350 homeless people inhabited shantytown in San Francisco's Civic Center plaza).

84. See, e.g., John Tierney, In Tunnel, 'Mole People' Fight to Save Home, N.Y. TMEs, June 13, 1990, at Al (approximately 100 people are inhabiting railroad tunnel beneath Riverside Park in New York City).

85. See People v. Sumlin, 431 N.Y.S.2d 967 (Crim. Ct. 1980) (defendant was guest of person living in abandoned building). 
compared to the area underneath a bridge abutment. Even in these more enclosed areas, however, it is unlikely that a shelterless person will be afforded any Fourth Amendment protection for her place of residence.

By virtue of their physical seclusion, these enclosed areas may be compared to residential dwellings. Nevertheless, it is unlikely that any of these areas will be classified as such for Fourth Amendment purposes. One of the defining features of shelterlessness is that a shelterless person, whether residing on public or private land, has no authority to exclude others from her premises. This absence of authority to exclude third parties means that even the more enclosed shelterless premises are subject to a risk of public scrutiny. As the courts' denial of protection to motel rooms after checkout or to the premises of trespassers indicates, this risk of public exposure is sufficient to prevent a place from qualifying for protected status as a residential dwelling. ${ }^{86}$

This type of risk analysis formed the basis for the denial of Fourth Amendment protection to shelterless premises in United States v. Ruckman ${ }^{87}$ and Commonwealth v. Camaroon. ${ }^{88}$ In Ruckman, the defendant was occupying a cave located on land owned by the United States and operated by the Bureau of Land Management. The defendant had been living in the cave for approximately eight months before the authorities discovered his presence. In the process of arresting the defendant, the authorities searched the cave and discovered a cache of illegal weapons.

The court denied the defendant's motion to suppress the weapons seized from the cave on the ground that the defendant lacked any expectation of privacy. According to the court, the defendant was a trespasser-his occupation of the cave was in "bad faith." 89 The court failed to indicate explicitly the significance of this bad faith possession, though its discussion of the open fields line of cases and Congress' plenary right to regulate public lands is highly revealing. ${ }^{90}$ This discussion suggests that the court viewed the defendant's bad faith possession as bearing on the question of the cave's exposure to the public. To the extent that the defendant lacked the power to exclude third parties from the cave, the cave was accessible to the public and thus outside the scope of Fourth Amendment protection.

86. See supra notes 44-47 and accompanying text; see also William S. McAninch, Unreasonable Expectations: The Supreme Court and the Fourth Amendment, 20 STETSON L. REV. 435, 442 (1991) (arguing that Supreme Court has imparted an assumption of risk analysis into Fourth Amendment jurisprudence, such that "so long as it is possible, no matter how unlikely, for a private person to have a particular vantage point and observe a particular place or activity, then it is unreasonable to expect privacy from such observation"); Note, From Private Places to Personal Privacy: A Post-Katz Study of Fourth Amendment Protection, 43 N.Y.U. L. REV. 968, 983 (1968) ("[T]n order for an expectation to be considered justified . . . it must be based on something in addition to a high probability of freedom from intrusion.").

87. 806 F.2d 1471 (10th Cir. 1986).

88. No. 02778 (Pa. Super. Ct. July 6, 1989).

89. Ruckman, 806 F.2d at 1474 (citing Amezquita v. Hernandez-Colon, 518 F.2d 8, 12 (1st Cir. 1975), cert. denied, 424 U.S. 916 (1976)).

90. Id. at 1472-73. 
In Camaroon, the defendant occupied premises even more sheltered than those at issue in Ruckman. In this case, the defendant was residing in an abandoned rowhouse. From the court's description, it is clear that the rowhouse closely approximated a traditional residential dwelling. According to the court, the house had no utilities or bathroom facilities, but it contained some furniture and a working television. ${ }^{91}$

Despite the more sheltered and residential nature of the premises in Camaroon, these premises were also denied protection as a Fourth Amendment house. While the court recognized that an individual need not have an actual ownership interest to possess a legitimate expectation of privacy in a place, it nonetheless insisted that, as a minimum, "there must be some legal or de facto right to control the area in question." ${ }^{.92}$ The court found that the defendant lacked any such right of control over the rowhouse. Thus, the court concluded that the rowhouse was exposed to "any other person who attempted to enter" and outside the range of dwellings entitled to Fourth Amendment protection. ${ }^{93}$

Both Ruckman and Cameroon appear only to have considered whether the shelterless premises in question were entitled to protection as residential dwellings. Those shelterless premises consisting of enclosed public areas, however, might also be compared to quasi-private public places. As the Supreme Court's decision in Katz v. United States indicates, the right to control is of much less significance with respect to these areas than with respect to residential dwellings. Katz suggests that the occupant of such an area need merely possess an informal right to use the area based on existing social practice. Society's failure to address the problem of shelterlessness ${ }^{94}$ can be viewed as the conferral of just such a right on the shelterless to use the public areas they inhabit as their homes.

91. No. 02778 , slip op. at 3 .

92. Id. at 6-7.

93. Id. at 7 .

94. In Lindsey v. Normet, the Supreme Court held that the U.S. Constitution affords no right to shelter. 405 U.S. 56 (1972). Most state courts have followed suit, refusing to find a constitutional right to shelter under state law. But see Callahen v. Carey, No. $42582 / 79$ (N.Y. Sup. Ct. Aug. 26, 1981) (New York Constitution entitles homeless to board and lodging). Thus, the task of providing shelter to the homeless has been left largely to the political branches.

Although President Bush has identified homelessness as one of the leading domestic problems facing his administration, DeParle, supra note 3, at A1, the federal government has taken no affirmative measures to provide shelter to the homeless, see Mitchel Levitas, Homeless in America, N.Y. TIMES, June 10, 1990, $\S 6$, at 45 (private agencies complaining that "the Feds have walked off the scene"). Several city and state legislatures have been more responsive. See, e.g., Mooney v. Pickett, 483 P.2d 1231 (Cal. 1971) (health and welfare statute requires each county to provide support to all poor and indigent persons); Hilton v. New Haven, No. 8904-3165 (Conn. Super. Ct. Dec. 27, 1989) (CONN. GEN. STAT. § 17-273 (1984) requires each town to provide homeless with shelter); Hodge v. Ginsburg, 303 S.E.2d 245 (W. Va. 1983) (state department of welfare statute entitles all incapacitated adults, including homeless, to shelter). Even in these jurisdictions, the allocation of governmental resources for the provision of temporary shelter has been inadequate. Frances E. Werner, Homelessness: A Litigation Roundup, 18 CLEARINGHOUSE REV. 1255, 1255 (1985). Thus, not only has there been no improvement in efforts to house the homeless, but the battle has been "losing ground." Levitas, supra, at 45 (citing remarks of Tulane University sociologist James D. Wright). 
No court has yet considered whether the shelterless inhabiting enclosed public areas are entitled to Fourth Amendment protection under the quasiprivate public area rubric. It is unlikely, however, that any court will extend protection based on this rationale-even if they accept the argument that society has tacitly consented to the use of enclosed public areas as residences for the shelterless. To date, the courts have limited the quasi-private public area designation to places whose use by any single individual is likely to be truly momentary. ${ }^{95}$ Indeed, it is the fact of momentary use which likely explains the courts' willingness to apply a less stringent definition of public exposure to quasi-private public areas. The habitation of a particular area, however, by its very nature, is an extended activity. Consequently, the very fact that an area is serving as a shelterless person's residence would seem to exclude it from any possible protection as a quasi-private public area.

There is one type of enclosed area in which the shelterless are likely to receive some Fourth Amendment protection: motor vehicles. Those shelterless inhabiting motor vehicles can expect to receive the same degree of protection afforded to other persons occupying automobiles. ${ }^{96}$ As Carney indicates, however, this protection will be less than that extended to persons inhabiting residential dwellings, despite the use of these vehicles as "homes."97 More important, this protection will benefit only the small percentage of shelterless persons possessing motor vehicles. For all practical purposes, therefore, only those homeless able to procure temporary space in a homeless shelter are likely to receive protection against unreasonable searches of their areas of residence under the courts' current understanding of Fourth Amendment houses. ${ }^{98}$ Those homeless unable to procure such shelter will find themselves not only without shelter from the elements, but also without shelter from the government.

\section{REEXAMINING the Foundation OF FOURTH AMENDMENT Houses}

The courts' adherence to the public exposure doctrine in Mooney, Ruckman, and Camaroon is an implicit statement that shelterless premises are similar to other areas deemed exposed to the public. Shelterless premises, however, are unlike other exposed areas, for they constitute the only place where shelterless individuals can engage in private activities. Denying Fourth Amendment protection to these areas, therefore, is tantamount to denying the shelterless any area where they may be free from governmental searches. In light of such a result, application of the public exposure doctrine to the shelterless is inconsis-

95. See supra text accompanying notes 66-70.

96. See supra notes $71-75$ and accompanying text.

97. See supra text accompanying notes 78-79.

98. For an argument that homeless shelters are sufficiently secluded from the public to qualify for Fourth Amendment protection as either commercial premises or residential dwellings, see Lasdon, supra note 7 , at $405-06$. 
tent with the Fourth Amendment goal of establishing a balance between law enforcement and freedom from governmental intrusion. ${ }^{99}$

\section{A. The Concept of Fourth Amendment Privacy}

Concluding that the denial of protection to shelterless premises fails to establish a proper Fourth Amendment balance requires an assessment of the scope of the Amendment's guarantee against freedom from intrusion. Only if this guarantee encompasses a shelterless person's interest in being free from governmental searches of his premises may violation of this interest be properly included in any subsequent Fourth Amendment calculus.

In the course of rejecting the trespass doctrine in Katz, Justice Stewart wrote that Fourth Amendment protections "often have nothing to do with privacy." 100 Despite this statement, privacy has come to be the central focus of Fourth Amendment jurisprudence. ${ }^{101}$ Such a result is a direct outgrowth of the Supreme Court's adoption of Harlan's two-part reasonable expectations test, with its emphasis on expectations of privacy as the determinant of Fourth Amendment interests.

To identify individual privacy as the basic concern of the Fourth Amendment, however, is only to begin to understand the scope of Fourth Amendment interests. Privacy is an evanescent term that has been used by scholars and courts alike to refer to a plethora of legally cognizable claims-including a

99. The design of the Fourth Amendment as an arbiter between the competing interests of freedom from governmental intrusion and efficient law enforcement is evidenced by its very language. Not only is Fourth Amendment protection limited to "searches and seizures" of "persons, houses, papers, and effects," but only "unreasonable" searches and seizures of these entities are prohibited. U.S. CONST. amend. IV. These limitations ensure that the Fourth Amendment right to freedom from governmental intrusion will not incapacitate society's legitimate interest in law enforcement, for every application of the Fourth Amendment "exacts a substantial social cost," Rakas v. Illinois, 439 U.S. 128, 137 (1978), particularly in light of the current remedy of exclusion of unconstitutionally obtained evidence. See YALE KAMISAR ET AL., MODERN CRIMTNAL PROCEDURE 18 (7th ed. 1990) ("Quite frequently, if the defendant gains suppression of unconstitutionally obtained evidence, there will be insufficientremaining evidence to continue with the prosecution."). By limiting the scope of unconstitutional governmental searches and seizures, therefore, the Fourth Amendment is designed to ensure a balance between its two competing concerns. This commitment to a balance between freedom from governmental intrusion and effective law enforcement constitutes the backdrop against which the validity of the public exposure doctrine, as applied to the shelterless, should be measured. $C f$. United States v. White, 401 U.S. 745, 786 (1971) (Harlan, J., dissenting) (scope of Fourth Amendment protections must be evaluated by "assessing the nature of the particular practice and the likely extent of its impact on the individual's sense of security balanced against the utility of the conduct as a technique of law enforcement"); Serr, supra note 28, at 584 ("The Supreme Court's task in interpreting the fourth amendment is to balance these two conflicting interests [the government's power to detect and redress violations of its laws and an individual's interest in a private life free from governmental intrusion] in a manner that promotes both.").

100. 389 U.S. 347,350 (1967).

101. See, e.g., Bivens v. Six Unknown Fed. Narcotics Agents, 403 U.S. 388, 408 (1971) (Harlan, J., concurring) ("The personal interests protected by the Fourth Amendment are those we attempt to capture by the notion of "privacy." "); Douse, supra note 22, at 156 ("[T]he Fourth Amendment is commonly considered to create a right to privacy ...."); Note, supra note 86 , at 968 ("[T] be looked upon as safeguarding an affirmative right of privacy." $)$. 
right to "mental repose," 102 "physical exclusiveness,"103 "control over knowledge about oneself,"104 and individual "autonomy."105 Any discussion of the Fourth Amendment as a guarantee of privacy, therefore, must define the nature of the legal claim encompassed within this guarantee.

The courts' reliance on the public exposure doctrine might suggest that the Fourth Amendment's protection of privacy may be adequately characterized as a nondisturbance right-the right to "physical exclusiveness." Most commentators agree, however, that Fourth Amendment privacy is more properly understood as encompassing a broader right to informational privacy-a right to "control over knowledge about oneself." 106 This conclusion finds support in both Fourth Amendment text and jurisprudence.

An understanding of Fourth Amendment privacy as simply a right to physical exclusiveness would render the Fourth Amendment's protection of "persons, houses, papers, and effects" 107 overinclusive. Such an understanding cannot account for the Amendment's expansive protection of private papers or effects. Merely extending protection against governmental intrusion into certain places could assure physical exclusiveness.

The Fourth Amendment's protection of papers and effects becomes explicable only when the scope of Fourth Amendment interests is expanded to include control over personal information. One's papers and effects, in addition to one's person and place of residence, constitute critical sources of personal information. ${ }^{108}$ Only by including these elements within the Fourth Amendment's guarantee against governmental intrusion could the Fourth Amendment provide

102. Gross, supra note 27 , at 37.

103. Id. at 37.

104. Charles Fried, Privacy, 77 YALE L.J. 475, 483 (1968); see also Douse, supra note 22, at 169 (most common definition of privacy is right of "individuals, groups, or institutions to determine for themselves when, how, and to what extent information about them is communicated to others").

105. Gross, supra note 27, at 38; see also Whalen v. Roe, 429 U.S. 589, 599-600 (1977) (right to privacy involves several different interests including "interest in avoiding disclosure of personal matter" and "interest in independence in making certain kinds of important decisions"). For a summary of the different legal interests that have been found to lie at the heart of the right to privacy, see ALAN R. WHITE, MISLEADING CASES 99-111 (1991). Once the right to privacy is viewed as a bundle of different legal claims, it is easier to reconcile Justice Stewart's rejection of privacy as the foundation of Fourth Amendment interests with the Supreme Court's subsequent embrace of privacy as the central focus of this provision. In $\mathrm{Katz}$, Stewart appears to have been using the term privacy in its broadest sense, as a shorthand reference to the entire set of claims comprising an individual's legal right to be left alone. It is for this reason that Stewart declared that "the Fourth Amendment cannot be translated into a general constitutional 'right to privacy." " Katz, 389 U.S. at 350. Thus, any apparent tension between Stewart's decision in Katz and later cases characterizing the Fourth Amendment as a guarantee of personal privacy is perhaps more semantic than substantive. See Douse, supra note 22, at 171 (noting different ways in which courts and commentators have used concept of privacy in context of Fourth Amendment).

106. See, e.g., Douse, supra note 22, at 182; Joseph D. Grano, Perplexing Questions About Three Basic Fourth Amendment Issues: Activity, Probable Cause, and the Warrant Requirement, 69 J. CRM. L. \& CRIMINOLOGY 425, 434 (1978); Jed Rubenfeld, The Right of Privacy, 102 HARV. L. REV. 737, 740 (1989); Tomkovicz, supra note 30 , at 661-67.

107. U.S. CONST. amend. IV.

108. Cf. WILLIAM JAMES, THE PRINCIPLES OF PSYCHOLOGY 291-305 (1902) (person's body, clothes, home, and other possessions comprise essence of his or her "material" self). 
a meaningful guarantee against governmental appropriation of personal information.

The type of activity proscribed by the Fourth Amendment also supports an informational conception of Fourth Amendment privacy. The specification of "searches and seizures" implies a concern about governmental efforts to acquire and appropriate data. ${ }^{109}$ Often, of course, these efforts are accompanied by a physical intrusion. Yet, particularly in this day and age, the government is capable of extracting information about its citizens without such an intrusion. ${ }^{110}$ Thus, a conception of Fourth Amendment privacy as merely a right to nondisturbance fails to capture the full import of the Fourth Amendment's prohibition of searches and seizures.

The Supreme Court recognized the Fourth Amendment's concern with the right of individuals to control the dissemination of personal information as early as Boyd v. United States, the Supreme Court's first major pronouncement on the scope of Fourth Amendment protection. ${ }^{111}$ In Boyd, the Court declared a federal law requiring compulsory production of commercial invoices unconstitutional. In support of its ruling, the Court emphasized the right of individuals not to divulge personal information. The Fourth Amendment, according to the Court, prevented the "forcible and compulsory extortion of a man's own testimony or of his private papers .... In this regard the Fourth and Fifth Amendments run almost into each other."112

Although the Court has since repudiated its holding in Boyd, ${ }^{113}$ it has nevertheless remained faithful to Boyd's underlying conception of the Fourth Amendment. Nowhere is this fidelity more evident than in Katz. In Katz, the Court realized that technological advances enabled the government to avoid the strictures of the Fourth Amendment by appropriating information without any corresponding physical intrusion. To prevent such a result, the Court shifted from property to privacy as the focus of Fourth Amendment interests. This shift allowed the Court to restore Boyd's vision of the Fourth Amendment as a bulwark against unlimited governmental appropriation of personal information-this time under the rubric of personal privacy. ${ }^{114}$ Thus, Katz stands as a testament to the informational character of Fourth Amendment privacy. ${ }^{115}$

109. John Applegate \& Amy Grossman, Comment, Pen Registers After Smith v. Maryland, 15 HARV. C.R.-C.L. L. REV. 754, 761 (1980); Tomkovicz, supra note 30, at 664-66.

110. See, e.g., Smith v. Maryland, 442 U.S. 735 (1979) (installation of pen register allowed government to discover telephone number dialed by defendant).

111. Boyd v. United States, 116 U.S. 616, 630 (1886).

112. Id. at 630 .

113. See Note, The Life and Times of Boyd v. United States (1886-1976), 76 MICH. L. REV. 184 (1977).

114. Amsterdam, supra note 36, at 384 ("Katz returned to the grand conception of Boyd v. United States.").

115. Grano, supra note 106, at 434; see also United States v. Karo, 468 U.S. 705, 712 (1984) (installation, though not monitoring, of beeper in defendant's can of ether permissible because it did not convey any "information which [defendant] wished to keep private"); United States v. Place, 462 U.S. 696, 707 (1983) (exposure of luggage to trained narcotics detection dog did not constitute Fourth Amendment search because "it [did] not expose noncontraband items that otherwise would remain hidden from public 


\section{B. The Public Exposure Doctrine in Perspective}

A conception of Fourth Amendment privacy as embodying a right to control over the dissemination of personal information has significant ramifications for how the term "houses" in the Fourth Amendment should be understood. Under such a conception of Fourth Amendment privacy, it makes little sense to interpret the term as referring exclusively to physical structures. There is nothing inherent in buildings designated as houses that makes them such critical sources of personal information that they need protection from the government. Rather, it is the activities that normally occur inside houses that warrant their protection. ${ }^{116}$ Consequently, to understand the Fourth Amendment as restricting the government's ability to discover personal information is to understand the term "houses" as protecting those activities normally associated with the home, wherever they occur. As a result, the Fourth Amendment's protection of houses is best understood as referring to places encompassing private activities, not to private places. ${ }^{117}$

Once the Fourth Amendment's protection of "houses" is understood as protecting private activities, it is clear that the special status the public exposure doctrine grants to secluded areas distorts the Amendment's protection of places. For members of society who are able to procure residential shelter, this distortion is insignificant. By virtue of the shelter that they possess, these individuals are able to conduct their private activities in areas secluded from the public. In effect, a doctrine focusing on private places extends protection to private activities. Thus, for individuals in possession of residential shelter, the public exposure doctrine portends no substantial loss of any protected privacy interests.

view").

116. See McAninch, supra note 86, at $436 \mathrm{n} .7$ (Fourth Amendment's protection of houses is "ultimately for the benefit of the householder rather than for the house itself").

117. Implicit in this conclusion, of course, is the notion that the privacy interests protected by the Fourth Amendment can actually be maintained in areas exposed to the public. If these interests are extinguished upon entering a public forum, it would make little sense to extend protection under the Katz test to such fora. To maintain that Fourth Amendment interests are extinguished upon entering a public forum, however, would confuse the right to physical exclusiveness with the right to control the flow of personal information. The latter interest retains significance even for one forced to live in the public domain, who has lost other privacy interests. As long as the government is prohibited from engaging in unreasonable searches of the premises of shelterless persons, these persons still retain the power to "control a small part of [their] environment . . . secure in the knowledge that [the government] cannot get at [them] without disobeying the Constitution." United States v. On Lee, 193 F.2d 306, 315-16 (2d Cir. 1951) (Frank, J., dissenting), aff' $d, 343$ U.S. 747 (1952).

The conclusion that Fourth Amendment privacy interests can survive in areas exposed to the public is supported by the courts' longstanding protection of the curtilage. See supra text accompanying notes $63-$ 65. Despite the open nature of this area, courts have included the curtilage within the ambit of Fourth Amendment protection on the grounds that the curtilage constitutes the "area to which extends the intimate activity associated with the 'sanctity of a man's home and the privacies of life." "Oliver v. United States, 466 U.S. 170, 180 (1984) (quoting Boyd v. United States, 116 U.S. 616, 630 (1886)). In short, the curtilage has received protection because it constitutes a locus for private activities. In protecting the curtilage, therefore, the courts have implicitly recognized that the Fourth Amendment's protection of houses is concerned about the use to which an area is put, not just the degree to which it is secluded from the public. 
Furthermore, whatever loss of privacy these individuals experience is outweighed by society's interest in law enforcement. The public exposure doctrine, by restricting Fourth Amendment protection to enclosed places, provides a clear demarcation between protected and unprotected areas. A doctrine that extended Fourth Amendment protection to areas exposed to the public would destroy this demarcation, thereby imposing an added burden on law enforcement officials. ${ }^{118}$ Since individuals possessing residential dwellings have no need to conduct private activities in areas exposed to the public, no sufficiently compelling reason exists for imposing this added burden. ${ }^{119}$

The same cannot be said with regard to the shelterless. These individuals have no enclaves of privacy in which to withdraw to conduct their private activities. Rather, the shelterless must conduct their daily affairs in areas exposed to the public. ${ }^{120}$ For the shelterless, private activities and private places diverge. Thus, as Part II indicates, a doctrine restricting Fourth Amendment protection to private places-such as the public exposure doctrine-denies the shelterless virtually any right to conduct private activities in a place free from governmental intrusion. As a result, the public exposure doctrine fails to strike an appropriate balance between the privacy interests of the shelterless and society's interest in effective law enforcement. ${ }^{121}$

118. Oliver, 466 U.S. at 181 (ad hoc approach to Fourth Amendment rights "not only makes it difficult for the policeman to discern the scope of his authority, it also creates a danger that constitutional rights will be arbitrarily and inequitably enforced").

119. Of course, to accept the public exposure doctrine as a valid framework for adjudicating the privacy interests of nonshelterless persons is not necessarily to accept the courts' particular applications of this doctrine. For an argument that the courts have interpreted the concept of public exposure too broadly, see Serr, supra note 28 , at 598-623.

120. It is this lack of choice that distinguishes the situation of a shelterless person from that of a person who is on a camping trip or a person who is living in a mobile home. Cf. California v. Carney, 471 U.S. 386 (1985) (warrantless search of mobile home used as defendant's residence did not violate Fourth Amendment). But $c f$. United States v. Ruckman, 806 F.2d 1471, 1475 (10th Cir. 1986) (McKay, J., dissenting) (arguing that even person temporarily camping in public domain is entitled to Fourth Amendment protection for "his temporary dwelling"). To the extent that the latter are living in the public domain of their own volition, they have not "done all that [they] could be reasonably expected to do to secure privacy." McAninch, supra note 86, at 471. If they are dissatisfied with their level of privacy, therefore, they can retire into more protected enclaves. This opportunity to escape to a more private enclave, at least in the short run, does not exist for the shelterless.

121. To determine whether a proper Fourth Amendment balance exists, of course, one should look to the Fourth Amendment as a whole. In many situations, for example, the Fourth Amendment's protection of effects can compensate for the absence of a Fourth Amendment house. See, e.g., Arkansas v. Sanders, 442 U.S. 753 (1978) ("automobile exception" justified warrantless search of taxi but not suitcase contained in trunk); United States v. Chadwick, 433 U.S. 1 (1977) (police permitted to remove but not search trunk found in parked car without warrant). In the absence of any Fourth Amendment protection for their areas of residence, however, the shelterless are unlikely to derive much benefit from the Amendment's protection of effects.

First, this protection only applies to those items concealed from plain view. United States v. Ross, 456 U.S. 798, 822-23 (1982). Most shelterless persons, however, do not possess closed containers in which to conceal their belongings. Their only opportunity for secreting their belongings is to store them where they live. If government officials are allowed unlimited access to these areas, even this method of storing belongings will fail to keep such belongings out of the plain view of government officials and within the Fourth Amendment's protection of effects. 


\section{BUILDING A NEW FOURTH AMENDMENT HOUSE FOR THE SHELTERLESS}

Given the public exposure doctrine's inappropriateness as a basis for adjudicating the Fourth Amendment rights of the shelterless, this Note proposes a new standard that focuses on private activities. This standard would require the courts to look to the type of activities conducted in the area subject to a police search, rather than to the area's degree of seclusion.

\section{A. The Private Activities Standard and the Katz Test}

A private activities standard could be adopted within the existing framework of the Katz test. In determining whether a Fourth Amendment search has occurred, the courts would still look to whether or not the target of a search had a reasonable expectation of privacy. If the search involved the residence of a shelterless person, however, the court would decide whether the expectation of privacy was reasonable based on a private activities standard, not the public exposure doctrine. The court would look to whether the shelterless person was using the area searched for activities ordinarily associated with the privacy of the home.

To make this determination, the courts could look to a variety of factors, including the type of activities occurring in the area, how long the area had been occupied, and whether other people inhabited the area. If these factors established that the shelterless person was using the searched area as her primary area of residence, then the second prong of the Katz test would be satisfied. Assuming the first, subjective prong of the Katz test were also satisfied, ${ }^{122}$ a search of the area would then be lawful only if conducted

Second, the Fourth Amendment's protection of effects only applies to items over which a person exercises constructive control. Abel v. United States, 362 U.S. 217, 241 (1960) (government may appropriate abandoned property); United States v. Kendall, 655 F.2d 199, 200 (9th Cir. 1981) ("A person who voluntarily abandons property has no standing to complain of its search and seizure."), cert. denied, 455 U.S. 941 (1982). This control has generally been found to exist only where the searched item was left in a private place, see, e.g., Chadwick, 433 U.S. 1 (defendant entitled to Fourth Amendment protection for trunk stored in parked car), or retained on or near the person objecting to the search, see, e.g., Sanders, 442 U.S. 753 (defendant entitled to Fourth Amendment protection for suitcase stored in trunk of taxi in which he was riding). In the absence of Fourth Amendment protection for their areas of residence, therefore, even those shelterless possessing closed containers will be entitled to Fourth Amendment protection only for those items that they are able to carry with them. Any items left behind at their place of residence will likely be deemed abandoned and outside the Fourth Amendment's scope. Cf. United States v. Oswald, 783 F.2d 663 (6th Cir. 1986) (defendant not entitled to Fourth Amendment protection for suitcase abandoned in burning car on highway); United States v. Brown, 473 F.2d 952 (5th Cir. 1973) (defendant not entitled to Fourth Amendment protection for suitcase abandoned in open field). But see State v. Mooney, 588 A.2d 145 (Conn.) (defendant who was incarcerated at time of search deemed not to have abandoned belongings left under bridge abutment where he was residing), cert. denied, 112 S. Ct. 330 (1991).

122. This prong would require a shelterless person to possess an actual expectation of privacy in a particular area before that area could qualify as a Fourth Amendment house. This prong could be used to prevent the shelterless from treating particularly public places as protected areas. Under this prong, the courts could look to the choices facing a shelterless person when determining whether that person was entitled 
pursuant to a warrant. Thus, in contrast to the public exposure doctrine, a private activities standard would better protect the shelterless against governmental intrusion by presenting them with an opportunity to claim certain publicly exposed areas as Fourth Amendment houses.

\section{B. The Public's Interest in Law Enforcement}

The key question is whether this added protection of the shelterless could be achieved without unduly burdening law enforcement activities. A private activities standard raises two primary concerns in this regard.

The first concern relates to the transient nature of shelterless persons. Given the highly mobile nature of shelterless persons and the absence of any structural markers denoting the existence of their premises, in many situations law enforcement officials are unlikely to know whether a particular area serves as a shelterless person's primary place of residence. Consequently, a private activities standard would appear to present the police with a Hobson's choice-either get a warrant for every search of the open fields or run the risk that the fruits of their search will be excluded at trial.

The harshness of this result could be tempered, however, by combining a private activities standard with a requirement of foreseeability. A foreseeability requirement could serve as part of the definition of a "reasonable" search of shelterless premises. The reasonableness of a search would depend not on the existence of a warrant, ${ }^{123}$ but rather on whether a law enforcement officer knew or should have known that a shelterless person was using the searched

to Fourth Amendment protection. If a shelterless person had the option of obtaining a private shelter, or could have found a less public place in which to reside, then the fact that the shelterless person chose to reside in the middle of Main Street would be probative of whether or not the shelterless person possessed an actual expectation of privacy. Consequently, when the two prongs of the $K a t z$ test are combined, a private activities standard would only extend Fourth Amendment protection to shelterless persons who attempted to find an enclave of privacy sheltered from public scrutiny.

The first prong of the Katz test is significant in another respect. It means that the courts would not be required at the outset of every suppression hearing to first determine whether an individual was shelterless or not. The courts would make this determination naturally in the course of applying the Katz test. If an individual was not shelterless, then her claim to privacy in the open fields would be rejected because she did not possess a subjective expectation of privacy under the first prong of the Katz test. In essence, then, this prong ensures that when an individual is not shelterless, a private activities doctrine collapses back into the public exposure doctrine. In the interests of judicial economy, therefore, the courts could simply adopt a private activities standard for all individuals, rather than apply one standard to shelterless individuals and a different standard to everyone else.

123. This latter criterion is the standard generally relied upon by the courts for evaluating the reasonableness of a Fourth Amendment search. See, e.g., United States v. United States Dist. Court, 407 U.S. 297, 315-16 (1972) ("[T]he definition of 'reasonableness' turns . . . on the more specific commands of the warrant clause."). A number of scholars have criticized the Court's collapsing of the reasonableness and warrant requirements. See, e.g., TELFORD TAYLOR, TWO STUDIFS IN CONSTITUTIONAL INTERPRETATION 98-100 (1969) (arguing that Fourth Amendment's two clauses were intended to be independent, with first clause regulating warrantless searches and second clause regulating searches conducted pursuant to warrant); Akhil R. Amar, The Bill of Rights as a Constitution, 100 YALE L.J. 1131, 1175-81 (1991) (arguing that purpose of warrant clause was not to define whether search was reasonable but to present government officials with procedural mechanism for avoiding civil liability). 
area as his home. ${ }^{124}$ This definition of a reasonable search would obviate the need to obtain a warrant for every open field search. A warrant would be required only in those situations where the presence of a Fourth Amendment house was clear. In all other situations, law enforcement officers would be free to engage in warrantless searches without any risk of adverse consequences.

A second concern raised by a private activities standard relates to the ability of government officials to enforce health and safety regulations. As shelterlessness increases, enforcement of health and safety regulations will require intrusions upon shelterless premises with increasing frequency. ${ }^{125}$ If officials were required to obtain a warrant for each intrusion, their ability to enforce these regulations would be severely undermined. ${ }^{126}$

This problem could be addressed by adopting a warrant procedure similar to that formulated by the Supreme Court in Camara v. United States. ${ }^{127}$ In Camara, the Court held that regulatory housing inspections could be performed without a traditional probable cause showing. The Court merely required that inspectors acquire warrants issued in accordance with "reasonable legislative or administrative standards" for conducting housing inspections. ${ }^{128} \mathrm{~A}$ similar warrant procedure could be applied to the performance of regulatory activities involving shelterless premises. Such a procedure would prevent government officials from having to make a traditional probable cause showing before enforcing health and safety regulations affecting the shelterless. At the same time, it would prevent them from using their regulatory authority as a pretext

124. This rejection of the traditional interpretation of the Fourth Amendment's reasonableness requirement is consistent with the trend established by several recent Supreme Court decisions. See, e.g., National Treasury Employees Union v. Von Raab, 489 U.S. 656 (1989) (reasonable search is one which is reasonable under circumstances); Skinner v. Railway Labor Executives Ass'n, 489 U.S. 602 (1989) (same). Prior to these decisions, the Court had recognized exceptions to the rule that warrantless searches were per se unreasonable only in a few, narrowly defined circumstances. See, e.g., Chimel v. California, 395 U.S. 752 (1969) (warrantless search reasonable if performed incident to arrest); Warden v. Hayden, 387 U.S. 294 (1967) (warrantless search reasonable if police are in hot pursuit).

125. This required intrusion will result from two types of enforcement activities: activities aimed at the premises inhabited by shelterless persons and activities aimed directly at the shelterless themselves. The former include housing inspectors checking the condition of abandoned buildings, highway inspectors examining overpasses and bridge abutments, and park authorities doing routine grounds keeping. See State v. Mooney, No. CR8-82728 (Conn. Super. Ct. May 12, 1988) (maintenance worker inspected bridge abutment where shelterless person was residing), rev'd on other grounds, 588 A.2d 145 (Conn.), cert. denied, 112 S. Ct. 330 (1991). The latter include health inspectors enforcing sanitation conditions in shelterless camps, social workers examining shelterless individuals for purposes of institutionalization, and police enforcing trespass and vagrancy laws against shelterless individuals. See, e.g., Kifner, supra note 83, at B1 (police ousted approximately 90 homeless from New York City's Tompkins Square Park); Port Authority Keeps Up Pace of Homeless Roundup, N.Y. TMES, Dec. 3, 1991 (police removed 60 people from Port Authority Bus Station for second straight day); Homeless Camp, supra note 83, at A10 (over 350 homeless evicted from San Francisco's Civic Center plaza).

126. Regulatory activities are designed to prevent the cccurrence of criminal or other activity likely to endanger the health or safety of society. Camara v. Municipal Court, 387 U.S. 523, 537 (1967). In order for such activities to be successful, therefore, they must often be performed before any notice of harmful activity exists. Id. This absence of notice makes the requirement of a warrant supported by probable cause particularly burdensome with regard to regulatory enforcement activities.

127. Id.

128. Id. at 538 . 
for unlimited intrusions on the shelterless. Only those intrusions supported by a warrant issued in accordance with prevailing regulatory standards would survive Fourth Amendment scrutiny. ${ }^{129}$

\section{The Private Activities Doctrine in Practice}

The ability of a private activities standard to maintain a proper balance between the rights of the shelterless and society's interest in effective law enforcement can be demonstrated by reconsidering Mooney, Ruckman, and Camaroon. Under the public exposure doctrine, each of the areas searched in these cases was denied protection as a Fourth Amendment house. A different result would obtain, however, if the courts relied on a private activities standard.

In each case, the defendants were using the areas searched by the police as their primary areas of residence. Furthermore, it appears that each of the defendants attempted to select areas as secluded from the public as possible. Thus, under a private activities standard, each of the defendants would have satisfied both prongs of the Katz test, thereby entitling their areas of residence to protection as Fourth Amendment houses.

This determination, of course, would not automatically render the police searches violative of the Fourth Amendment. It would require, however, that the police searches satisfy the requirement of reasonableness, by demonstrating that the police did not know or have reason to know that a shelterless person was using the area as his area of residence.

Clearly, the searches in both Mooney and Ruckman would fail this requirement. The patrolmen in Mooney knew from their conversation with the defendant's girlfriend that the defendant was residing at the area underneath the bridge abutment. Similarly, the government agents in Ruckman knew that the defendant was living in the cave on government land. In both cases, therefore, the police were clearly apprised that they were invading a shelterless person's home. This knowledge would render the searches unreasonable under a private activities standard and invalid under the Fourth Amendment.

By contrast, the police in Camaroon had no knowledge that the defendant was residing in the abandoned rowhouse. Indeed, the day just prior to the search, the police had entered the building and had seen no sign of habita-

129. Even an intrusion according with prevailing regulatory policy would not permit a government official to engage in a search of a shelterless person's premises that was unrelated to the purpose of the intrusion. A government official could, however, seize any evidence that, in the process of his intrusion, was inadvertently discovered in plain view. The possession of a Camara-type warrant would satisfy the requirement that a plain view seizure be preceded by a legitimate entry onto the premises. Coolidge v. New Hampshire, 403 U.S. 443, 466 (1971) (plain view doctrine applies only when police officer has "prior justification for an intrusion"). 
tion..$^{130}$ As a result, the police search in Camaroon would satisfy the reasonableness requirement under a private activities standard.

The foregoing discussion indicates that a standard focusing on private activities would not invalidate all searches of the areas shelterless people inhabit. Rather, such a standard would simply prevent searches of these areas from being automatically excluded from the Fourth Amendment's protection of houses. Under a private activities standard, therefore, the Fourth Amendment inquiry in cases involving shelterless persons would focus on the reasonableness of the search in each particular case, thereby bringing Fourth Amendment jurisprudence into consonance with a fundamental tenet of our criminal justice system: that an individual's rights should not depend on "the amount of money he has." 131

\section{CONCLUSION}

The burgeoning shelterless population has rendered the courts' understanding of Fourth Amendment "houses" obsolete. The post-Katz shift from private property to private places as the defining criterion of Fourth Amendment "houses"-though responsive to advances in governmental surveillance-inadequately protects the rights of those forced to inhabit areas exposed to the public. To protect the rights of these individuals, the courts need to alter their understanding of Fourth Amendment houses once again - this time by shifting their focus from private places to private activities.

130. Camaroon, No. 02778, slip op. at 2 (Pa. Super. Ct. July 6, 1989). Arguably, however, the police officer should have known that the defendant was using a portion of the abandoned rowhouse as his residence. Before searching the room where the defendant was living, the officer peeked through the keyhole and saw various signs of habitation, including a couch, a table with food on it, and a television set. Id. at 3.

131. Griffin v. Illinois, 351 U.S. 12,19 (1956). 